\title{
PENILAIAN KINERJA SAHAM PADA PELAKSANAAN IPO DITINJAU DARI UNDERPRICING DAN MARKET OVERREACTION
}

\author{
Desta Rizky Kusuma \\ Universitas Ahmad Dahlan \\ e-mail: kusuma.desta@gmail.com
}

\begin{abstract}
ABSTRAK
This study aims to determine the short-term and long-term stock performance after the IPO and market overreaction symptoms in IDX. In terms of performance shares underprice stocks, short-term performance share is calculated one month after the IPO and long-term calculated six months after the IPO. The data sample are firms listed on the IDX of IPOs in the year 2000 - 2007, obtaining a sample of 102 firms. Based on the analysis, the short-term stock performance post-IPO can provide a positive abnormal return and long stock performance post-IPO will go down or decline (long run underperformance). The results showed no symptoms of market overreaction, because there is no relationship in the opposite pattern of abnormal returns earned on short-term and long term.
\end{abstract}

Keywords: IPO (Initial Public Offering), Underpricing, Market Overreaction

\begin{abstract}
PENDAHULUAN
Salah satu cara bagi perusahaan untuk mendapatkan tambahan dana guna mengembangkan usahanya adalah dengan melakukan Go Public. Dengan melakukan go public maka dapat memperkuat modal kerja perusahaan, hal ini disebabkan karena sahamsaham perusahaan dapat dimiliki masyarakat secara umum. Perusahaan yang belum go public awalnya saham-saham perusahaan dimiliki oleh manajer dan pegawai-pegawai kunci, dan hanya sebagian kecil hak kepemilikan dimiliki oleh investor.
\end{abstract}

Perusahaan yang akan melakukan go public terlebih dahulu harus menerbitkan saham pertamanya yang ditawarkan di Pasar Perdana (Primary Market) atau sering disebut dengan pelaksanaan IPO (Initial Public Offering). Pada pasar perdana inilah perusahaan mendapatkan tambahan dana dari investor atas penjualan saham, untuk selanjutnya saham tersebut diperjual belikan oleh para broker/ investor setelah saham tersebut dicatatkan di pasar sekunder.

Pada saat perusahaan memutuskan untuk melakukan IPO, sebelumnya perusahaan harus mengeluarkan informasi mengenai perusahaan (prospektus). Prospektus berfungsi untuk memberikan informasi mengenai perusahaan kepada calon investor, sehingga calon investor dapat mengetahui kondisi perusahaan dan prospeknya di masa mendatang dan selanjutnya diharapkan calon investor tertarik untuk membeli saham yang diterbitkan perusahaan atau emiten.

Permasalahan penting dalam melakukan penawaran saham perdana di pasar modal adalah dalam hal penetapan harga penawaran saham. Harga saham yang ditawarkan pada saat melakukan IPO merupakan faktor penting untuk menentukan besarnya dana yang diterima emiten. Jika harga saham tinggi maka dana yang diterima semakin besar dan juga sebaliknya, sehingga 
emiten selalu mengharapkan harga saham yang tinggi.

Akan tetapi, hal tersebut bertentangan dengan apa yang diinginkan investor. Investor biasanya menginginkan harga yang relatif rendah, yang nanti akan dapat mempengaruhi capital gain yang diperoleh investor saat menjual kembali saham tersebut di pasar sekunder. Untuk itulah emiten harus dapat menentukan harga saham perdana secara bijak, disamping melihat keuntungan yang diperoleh tapi juga melihat dari segi investor. Karena jika harga yang ditetapkan terlalu tinggi, besar kemungkinan calon investor tidak mau menanamkan modalnya dan hal ini justru malah akan berdampak buruk terhadap perusahaan.

Dalam penentuan harga saham IPO, perusahaan atau emiten bekerja sama dengan penjamin emisi (underwriter). Underwriter yang ditunjuk perusahaan bertugas untuk membantu serta memberikan saran dalam penetapan harga saham perdana sekaligus membantu dalam memasarkan saham tersebut kepada calon investor. Terdapat dua model penjaminan yang dapat dipilih perusahaan dalam pelaksanaan IPO, yaitu best effort dan firm commitment. Pada model best effort penjamin emisi hanya menjualkan saham emiten dengan usaha semaksimal mungkin untuk mendapatkan harga penjualan sebaik mungkin, dan mendapat komisi dari emiten atas usahanya. Sedangkan pada model firm commitment, underwriter membeli semua saham yang diterbitkan dengan harga yang telah disetujui dan menanggung risiko kegagalan untuk menjualnya kembali ke publik. Dalam hal ini underwriter mengambil keuntungan dari selisih harga beli dengan harga jual saham (spread). Dari model penjaminan tersebut dapat disimpulkan bahwa risiko yang ditanggung oleh penjamin emisi lebih besar dibanding dengan perusahaan emiten jika menggunakan model firm commitment, dan juga sebaliknya.
Para investor menginvestasikan dananya pada pasar perdana mempunyai tujuan untuk mendapatkan keuntungan berupa initial return, yaitu selisih lebih antara harga saham di pasar sekunder dengan harga perdananya. Terjadinya initial return ini menunjukkan adanya peristiwa underpricing saham. Underpricing terjadi jika harga yang ditawarkan pada pasar perdana secara signifikan lebih rendah dibandingkan dengan harga saham pada saat hari pertama di pasar sekunder. Tentunya kejadian seperti ini yang diharapkan oleh investor karena dapat memberikan abnormal return yang lebih.

Underpricing yang sering terjadi pada pelaksanaan IPO disebabkan adanya asimetri informasi di pasar perdana (Schlag dan Wodrich, 2000. Dalam Supriyono, 2006: 53). Informasi asimetri ini dapat terjadi antara emiten dengan penjamin (Baron, 1982) atau antara investor informed dengan uninformed (Rock, 1986. Dalam Suyatmin dan Sujadi, 2006: 12).

Penjamin emisi memiliki informasi yang lebih dibandingkan dengan perusahaan emiten tentang permintaan terhadap saham. Dalam hal ini penjamin emisi akan memanfaatkan kelebihannya untuk mengajukan kesepakatan harga yang relatif rendah dengan tujuan untuk mengurangi risiko yang ditanggungnya jika saham tidak terjual. Perusahaan emiten menerima kesepakatan tersebut disebabkan kurangnya informasi.

Investor asimetri juga terdapat pada informed investor dengan uninformed investor. Informed investormemilikilebihbanyakinformasi mengenai kondisi dan prospek emiten sehingga mereka hanya akan menanamkan dananya pada saham yang underpriced. Sedangkan untuk uninformed investor tidak dapat mengetahui saham mana yang menguntungkan bagi mereka karena kurangnya informasi mengenai emiten. Supaya kelompok uninformed ini juga turut serta dalam investasi saham, maka perusahaan emiten menerima underpriced dalam pelaksanaan IPO nya. 
Dalam penawaran saham perdana terkadang pula terjadi gejala market overreaction, yaitu keadaan dimana telah terjadi reaksi yang berlebihan dari investor tentang emisi saham baru. Gejala ini dapat dilihat dengan hubungan antara initial return dengan return saham tersebut dalam jangka panjang.

Penelitian ini bertujuan untuk menganalisis: (1) apakah terjadi underpricing pada pelaksanaan IPO di Bursa Efek Indonesia? (2) apakah kinerja saham jangka pendek setelah IPO dapat memberikan abnormal return? (3) apakah kinerja saham setelah IPO dapat menurun dalam waktu jangka panjang atau telah terjadi market overreaction pada bursa efek indonesia?

\section{REVIEW LITERATUR DAN HIPOTESIS}

\section{IPO (Initial Public Offering) /Penawaran Umum Perdana}

Initial Public Offering (IPO) atau disebut juga unseasoned equity offering merupakan peristiwa yang penting bagi perusahaan, dalam hal ini perusahaan menawarkan saham pada publik untuk yang pertama kali. Dengan melakukan IPO, perusahaan akan mendapatkan tambahan dana yang dapat dipergunakan untuk pengembangan usahanya.

Sebagian besar menganggap bahwa IPO merupakan cara yang mudah dan murah bagi perusahaan untuk memenuhi kebutuhan dana sebagai konsekuensi dari semakin berkembangnya perusahaan dan meningkatkan kebutuhan dana untuk investasi.

Manfaat IPO

Berikut ini adalah manfaat dari pelaksanaan IPO (Jogiyanto, $2003: 17$ )

1. Kemudahan meningkatkan modal di masa mendatang.

Untuk perusahaan yang tertutup, calon investor biasanya enggan untuk menanamkan modalnya disebabkan kurangnya keterbukaan informasi keuangan antara pemilik dan investor. Sedang untuk perusahaan yang sudah go public, informasi keuangan harus dilaporkan ke publik secara reguler yang kelayakannya sudah diperiksa oleh akuntan publik.

2. Meningkatkan likuiditas bagi pemegang saham.

Untuk perusahaan yang masih tertutup yang belum mempunyai pasar untuk sahamnya, pemegang saham akan lebih sulit untuk menjual sahamnya dibandingkan jika perusahaan sudah go public.

3. Nilai pasar perusahaan diketahui.

Untuk alasan-alasan tertentu, nilai pasar perusahaan perlu untuk diketahui. Misalnya jika perusahaan ingin memberikan insentif dalam bentu opsi saham (stock option) kepada manajer-manajernya, maka nilai sebenarnya dari opsi tersebut perlu diketahui. Jika perusahaan masih tertutup, nilai dari opsi sulit ditentukan.

\section{Penetapan Harga Penawaran Saham}

Persoalan penting yang dihadapi perusahaan ketika melakukan penawaran saham perdana di pasar modal adalah penetapan besarnya harga penawaran perdana. Penetapan pada harga berapa sebuah saham seharusnya ditawarkan kepada calon pembeli merupakan pekerjaan yang tidak mudah, karena suatu kesalahan kecil dapat menyebabkan gagalnya suatu IPO. Harga saham yang ditawarkan pada saat melakukan IPO merupakan faktor penting yang menentukan besarnya jumlah dana yang diperoleh perusahaan (emiten). Jika harga saham tinggi, maka dana yang diperoleh emiten juga besar dan begitu pula sebaliknya. Hal tersebut membuat emiten mengharapkan harga yang tinggi.

Namun di pihak lain, investor tentunya menginginkan harga saham perdana yang relatif rendah sehingga mereka nantinya akan mendapatkan keuntungan (capital gain) di pasar sekunder pada saat menjualnya kembali kepada 
investor lainnya. Sebaliknya, harga perdana yang tinggi akan mengurangi atau bahkan menghilangkan return awal (initial return) yang bisa diperoleh oleh investor di bursa.

Olehkarenaitu,perusahaan(emiten) dalam menentukan harga perdana bekerja sama dengan penjamin emisi (underwriter). Underwriter yang ditunjuk perusahaan bertugas membantu serta memberikan saran dalam penetapan harga saham perdana sekaligus membantu dalam memasarkan saham tersebut kepada calon investor.

Harga saham pada penawaran perdana ditentukan berdasar kesepakatan antara emiten denganpenjaminemisi.Biasanyaunderwriterakan bernegosiasi dengan emiten untuk menetapkan harga yang ditawarkan relatif rendah atau tidak terlalu mahal. Hal ini dilakukan penjamin emisi (terutama full commitment) dengan maksud untuk mengurangi dan memperkecil risiko kerugian yang ditanggung oleh underwriter jika saham yang ditawarkan tidak laku dijual.

\section{Underpricing}

Para investor yang menanamkan dananya di pasar perdana (primary market) mempunyai tujuan untuk memperoleh initial return yang diperoleh dari selisih lebih antara harga di pasar sekunder dengan harga perdana. Adanya initial return tersebut mengindikasikan bahwa terjadi underpricing saham di pasar perdana ketika masuk ke pasar sekunder. Underpricing terjadi jika harga yang ditawarkan pada pasar perdana secara signifikan lebih rendah dibandingkan dengan harga saham pada saat hari pertama di pasar sekunder. Underpricing hampir terjadi di setiap pasar modal. Hal ini didukung hasil penelitian Supriyono (2005), Hanafi (1997) dan Rufnialfan (1999).

\section{Kinerja Saham IPO}

Perbedaan harga saham akan diterima oleh investor sebagai abnormal return. Besarnya abnormal return yang diterima oleh investor dapat menunujukkan kinerja saham tersebut. Semakin besar abnormal return yang diterima investor menunjukkan bahwa kinerja saham tersebut semakin baik, dan sebaliknya semakin kecil abnormal return yang diterima investor maka kinerja saham tersebut semakin rendah. Besar kecilnya kinerja saham dapat dipengaruhi oleh time horizon dari investor (Murtini, 2005). Time horizon setiap investor berbeda (bisa jangka pendek maupun jangka panjang), dan time horizon akan mempengaruhi kinerja saham baik untuk jangka pendek maupun jangka panjang.

Sejumlah studi mencatat bahwa saham IPO memberikan abnormal return positif dalam periode jangka pendek sesudah IPO atau biasa disebut dengan istilah short run underpricing (Tinic, 1988) dalam Suroso dan Utama (2005). Yang dimaksud jangka pendek tersebut adalah waktu dari pembelian saham di pasar perdana sampai dengan periode awal saham-saham IPO tersebut diperdagangkan di pasar sekunder.

Sebaliknya, bahwa saham IPO akan menunjukkan kinerja yang lebih rendah dalam jangka panjang setelah IPO, disebut isstilah long run underperfomance (Ritter, 1991) dalam Suroso dan Utama (2005). Kedua hal ini konsisten dengan hasil penelitian Suroso (2005), Supriyono (2005) dan Murtini (2005).

\section{Market Overreaction}

Fenomena market overreaction pada mulanya dikenalkan oleh De Bondt dan Thaler (1985) dalam Supriyono (2005) dan hasil penelitiannya Supriyono menemukan bahwa saham yang pada mulanya memberikan tingkat keuntungan sangat positif (winner) atau sangat negatif (losser) akan mengalami kondisi yang berkebalikan pada periode-periode selanjutnya. Lebih lanjut Supriyono (2005) dalam hasil penelitiannya menyebutkan bahwa pasar bereaksi berlebihan (overreaction) terhadap informasi, dimana pasar bereaksi berlebihan terhadap informasi baru dan mengabaikan 
informasi sebelumnya. Pembalikan return terjadi ketika pasar menyadari kesalahan tersebut dan kemudian melakukan tindakan koreksi pada periode selanjutnya.

Ritter (1991) dalam Manurung dan Soepriyono (2006) juga menjelaskan bahwa pada market overreaction sebenarnya harga penawaran saham yang telah ditetapkan oleh underwriter telah sesuai dan initial return yang positif merupakan akibat dari reaksi berlebihan dari investor yang tidak rasional. Argumentasi ini diajukan terutama didasarkan pada psikologi dan tingkah laku (behavior) atau ketidak-rasionalan dari investor.

\section{Hipotesis}

Berdasarkan dari penjelasan dan penelitian-penelitian sebelumnya, maka dirumuskan hipotesis:

$\mathrm{H}_{1}=$ Diduga terjadi underpricing yang signifikan pada pelaksanaan IPO di Bursa Efek Indonesia.

$\mathrm{H}_{2}=$ Diduga kinerja saham jangka pendek setelah IPO dapat memberikan abnormal return positif.

$\mathrm{H}_{3}=$ Diduga kinerja saham setelah IPO akan cenderung menurun dalam waktu jangka panjang.

$\mathrm{H}_{4}=$ Diduga telah terjadi market overreaction di Bursa Efek Indonesia.

\section{METODE PENELITIAN}

\section{Populasi dan Sampel}

Pengambilan sampel dalam penelitian ini menggunakan purposive sampling. Sampel berjumlah 102 perusahaan, dipilih dengan menggunakan kriteria sebagai berikut:

1. Perusahaan yang terdaftar di BEI.

2. Perusahaan yang melakukan penawaran saham perdana (IPO) pada periode 20002007.

3. Perusahaan yang mengalami underpricing.

\section{Definisi Operasional Variabel Penelitian}

1. Underpricing menggambarkan initial return saham berupa selisih antara harga penutupan saham (closing price) pada hari pertama perdagangan di pasar sekunder dengan harga perdananya (offering price). Variabel ini diukur dengan persentase, dengan rumus sebagai berikut:

$$
\text { Underpricing }=\frac{(C P-O P)}{O P} \times 100 \%
$$

Keterangan:

$\mathrm{CP}=$ Harga penutupan pada hari pertama perdagangan di pasar sekunder. $\mathrm{OP}=$ Harga penawaran perdana.

2. Untuk kinerja saham atau perusahaan yang melaksanakan IPO diukur dengan melihat perbandingan abnormal return pada saat satu bulan (jangka pendek) setelah IPO hingga enam bulan setelah IPO (jangka panjang), dimana abnormal return menunjukkan selisih antara return yang sesungguhnya dengan return yang diharapkan, dengan menggunakan rumus sebagai berikut:

$$
\mathrm{AR}_{\mathrm{t}}=\mathrm{r}_{\mathrm{it}}-\mathrm{E}\left(\mathrm{r}_{\mathrm{it}}\right)
$$

Untuk mencari return, digunakan dasar pada harga penawaran perdana, dengan rumus sebagai berikut:

$$
r=\frac{P t-O P}{O P}
$$

\section{Keterangan:}

$\mathrm{AR}_{\mathrm{t}} \quad$ : abnormal return (return tidak normal) pada periode $\mathrm{t}$.

$\mathrm{r}_{\text {it }} \quad$ : return sesungguhnya pada periode $\mathrm{t}$.

$\mathrm{P}_{\mathrm{t}} \quad$ : harga saham pada periode $\mathrm{t}$.

OP : harga penawaran perdana.

$\mathrm{E}\left(\mathrm{r}_{\mathrm{it}}\right)$ : expected return (return yang diharapkan) pada periode $\mathrm{t}$.

Return yang diharapkan dalam penelitian ini adalah dengan menggunakan market adjusted 
model, yang menyatakan bahwa koreksi terbaik untuk mengestimasi return suatu saham return pasar $\left(\mathrm{r}_{\mathrm{mt}}\right)$ saat itu.

Untuk mencari return market dapat digunakan rumus sebagai berikut:

$$
R m=\frac{P m t}{P m 0}-1
$$

Keterangan:

$\mathrm{P}_{\mathrm{mt}}$ : nilai indeks pasar pada saat $\mathrm{t}\left(\mathrm{IHSG}_{\mathrm{t}}\right)$

$\mathrm{P}_{\mathrm{m} 0}$ : nilai indeks pasar pada saat penawaran

Dengan demikian rumus abnormal return yang baru adalah:

$$
\mathrm{AR}_{\mathrm{t}}=\mathrm{r}_{\mathrm{it}}-\mathrm{r}_{\mathrm{mt}}
$$

Abnormal Return digunakan sebagai pengukur kinerja saham, dengan kriteria:

Abnormal Return $>0$, menunjukkan kinerja yang outperfomance (baik).

Abnormal Return $<0$, menunjukkan kinerja yang underperfomance (kurang baik).

3. Overreaction menggambarkan kondisi dimana telah terjadi reaksi yang berlebihan dari investor akan emisi saham baru. Ini dapat dilihat dari apakah ada hubungan antara initial return dengan return saham tersebut dalam jangka panjang.

Perhitungan market overreaction dalam penelitian ini, initial return pada hari pertama digunakan untuk menentukan rentang abnormal return negatif dan positif. Untuk periode selanjutnya (bulan ke-1 sampai dengan bulan ke-6) baru dikelompokkan return yang masuk ke dalam rentang abnormal return negatif dan positif yang telah ditentukan, setelah itu baru dihitung rata-rata abnormal return nya.

\section{Analisis Data}

Alat analisis data yang digunakan dalam penelitian ini adalah dengan Uji Beda. Uji beda digunakan untuk membuktikan apakah kinerja saham jangka pendek mengalami perubahan yang signifikan setelah jangka panjang. Uji beda yang digunakan adalah one-sample t-test.

Pengolahan data dilakukan dengan alat bantu program excel, yang digunakan untuk menghitung underpricing, return, abnormal return dan return pasar. Sedang untuk mengetahui kinerja saham jangka pendek dan jangka panjang pasca IPO dilakukan dengan alat bantu software SPSS for windows 15.0.

\section{HASIL PENELITIAN DAN PEMBAHASAN}

1. Untuk menguji hipotesis pertama, yaitu untuk mengetahui apakah terjadi underpricing yang signifikan dengan menggunakan uji $\mathrm{t}$ (uji beda one sample t-test). Uji ini digunakan untuk membandingkan apakah suatu nilai tertentu (sebagai pembanding) berbeda secara signifikan dengan rata-rata suatu sampel yang dalam penelitian ini adalah data underpricing. Sedangkan nilai tertentu dalam penelitian ini adalah nilai nol (0) yang berarti bahwa harga perdana sama dengan harga penutupan hari pertama (truepricing).

Berikut adalah hasil dari uji one sample t-test (uji signifikansi underpricing).

Tabel 1

Hasil Uji t (data underpricing)

One-Sample Test

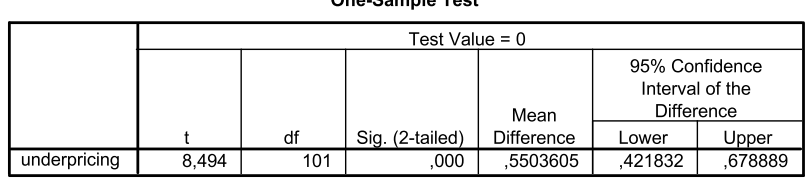

Berdasarkan tabel di atas dapat dilakukan pengujian sebagai berikut:

Karena nilai sign. sebesar $0,000<$ alpha $(0,05)$ maka disimpulkan menerima hipotesis penelitian $\left(\mathrm{H}_{1}\right)$ yang berarti bahwa telah terjadi underpricing yang signifikan di BEI tahun 2000 - 2007.

2. Pada hipotesis kedua, cara pengujiannya adalah dengan melihat signifikansi kenaikan 
abnormal return (kinerja saham) dalam jangka pendek. Namun sebelum dilakukan pengujian, terlebih dahulu dicari signifikansi abnormal return nya. Signifikansi abnormal return diperoleh dengan menggunakan uji $\mathrm{t}$ one sample t-test, yaitu membandingkan antara rata-rata abnormal return dengan nilai tertentu. Nilai tertentu yang digunakan sebagai pembanding adalah nol (0), karena pada saat abnormal return sebesar nol (0) maka return saham akan sama dengan return pasarnya.

Tabel 2

\section{Hasil Uji t (data abnormal return dari hari ke-1 sampai bulan ke-1)}

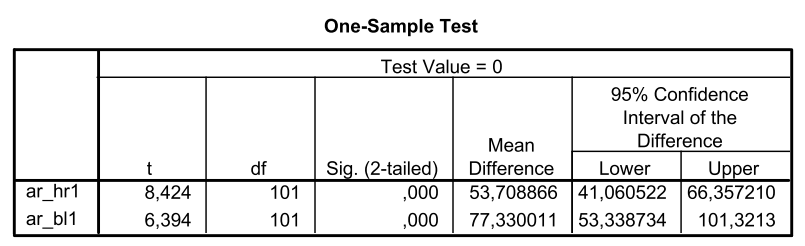

Berdasarkan dari tabel tersebut, diketahui bahwa Sig. (2 tailed) untuk abnormal return hari ke-1 dan bulan ke-1 adalah sama yaitu sebesar 0,000. Karena nil sig. $(0,000)<$ alpha $(0,05)$, maka dapat disimpulkan bahwa abnormal return yang terjadi pada hari ke-1 dan bulan ke-1 adalah signifikan.

Selanjutnya untuk lebih jelas mengenai pola pergerakan abnormal return dalam jangka pendek, disajikan dalam bentuk tabel berikut ini.

Tabel 3

Kinerja Saham (jangka pendek) setelah IPO tahun 2000 - 2007

Pada Basis Harga Penawaran Perdana

\begin{tabular}{|l|c|c|c|}
\hline \multicolumn{1}{|c|}{ Periode } & Sampel & Rata-rata AR (\%) & Sig. (2 tailed) \\
\hline Hari ke-1 & 102 & 53,71 & $0,00^{*}$ \\
\hline Bulan ke-1 & 102 & 77,33 & $0,00^{*}$ \\
\hline
\end{tabular}

Keterangan: ${ }^{*}$ Signifikan pada level $5 \%$

Dari tabel tersebut, dapat diketahui bahwa terdapat kenaikan abnormal return yang signifikan dari hari pertama sampai bulan ke-1 (jangka pendek). Abnormal return pada hari pertama perdagangan rata-rata sebesar 53,71\%, lalu mengalami kenaikan secara signifikan pada bulan ke-1 sebesar $77,33 \%$. Hal ini berarti telah terjadi kenaikan kinerja saham sebesar $23,62 \%$. Dengan demikian hipotesis kedua yang menyatakan kinerja saham jangka pendek setelah IPO memberikan abnormal return positif (mengalami outperfomance) dapat diterima.

3. Pada hipotesis ketiga, cara pengujiannya sama seperti hipotesis kedua, terlebih dahulu dicari signifikansi abnormal return nya dengan menggunakan uji one sample t-test.

Tabel 4

\section{Hasil Uji t (data abnormal return dari hari ke-1 hingga bulan ke-6)}

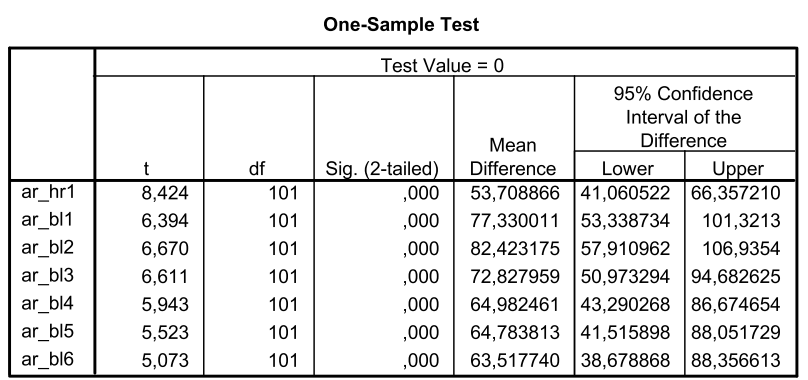

Berdasarkan dari tabel tersebut, diketahui bahwa Sig. (2 tailed) untuk abnormal return dari hari ke-1 hingga bulan ke-6 adalah sama yaitu sebesar 0,000 . Karena nil sig. $(0,000)<$ alpha $(0,05)$, maka dapat disimpulkan bahwa abnormal return yang terjadi dari hari ke-1 hingga bulan ke-6 adalah signifikan.

Berdasarkan tabel 5, dapat diketahui bahwa ada abnormal return yang signifikan sampai dengan bulan ke-6. Abnormal return pada hari pertama perdagangan rata-rata sebesar 53,71\%, lalu mengalami kenaikan berturut-turut secara signifikan pada bulan ke-1 sebesar 77,33\% dan bulan ke-2 sebesar $82,42 \%$ setelah itu mengalami penurunan yang signifikan menjadi sebesar $63,52 \%$ 
pada bulan ke-6. Hal ini berarti telah terjadi penurunan kinerja saham sebesar 13,81\% dari bulan ke-1 hingga bulan ke-6. Dengan demikian menerima hipotesis ketiga, yaitu kinerja saham setelah IPO dalam jangka panjang akan mengalami penurunan, terbukti pada bulan ke-6 mengalami penurunan abnormal return yang signifikan.

\section{Tabel 5}

Kinerja Saham (jangka panjang) setelah IPO tahun 2000 - 2007

\section{Pada Basis Harga Penawaran Perdana}

\begin{tabular}{|l|c|c|c|}
\hline \multicolumn{1}{|c|}{ Periode } & Sampel & Rata-rata AR (\%) & Sig.(2 tailed) \\
\hline Hari ke-1 & 102 & 53,71 & $0,00^{*}$ \\
\hline Bulan ke-1 & 102 & 77,33 & $0,00^{*}$ \\
\hline Bulan ke-2 & 102 & 82,42 & $0,00^{*}$ \\
\hline Bulan ke-3 & 102 & 72,83 & $0,00^{*}$ \\
\hline Bulan ke-4 & 102 & 64,98 & $0,00^{*}$ \\
\hline Bulan ke-5 & 102 & 64,78 & $0,00^{*}$ \\
\hline Bulan ke-6 & 102 & 63,52 & $0,00^{*}$ \\
\hline
\end{tabular}

Keterangan: *) Signifikan pada level 5\%

4. Untuk menguji hipotesis yang terakhir adalah dengan melihat pola hubungan initial return dengan return saham tersebut dalam jangka panjang. Market overreaction terjadi bila saham yang pada awalnya memberikan tingkat keuntungan sangat positif (winner) atau sangat negatif (losser) akan mengalami kondisi yang berkebalikan pada periodeperiode selanjutnya.

\section{Tabel 6}

\section{Hubungan Abnormal Return Jangka Pendek dan Jangka Panjang}

Pada Basis Harga Penawaran Perdana

\begin{tabular}{|c|c|c|c|c|c|}
\hline \multicolumn{2}{|c|}{ Hari ke-1 } & \multicolumn{2}{c|}{ Bulan ke-1 } & \multicolumn{2}{c|}{ Bulan ke-6 } \\
\hline Kel. AR & N & Mean AR (\%) & N & Mean AR (\%) & N \\
\hline$-4 \%-0$ & 1 & $-1,82 \%$ & 9 & $-2,31 \%$ & 3 \\
\hline $\begin{array}{c}0,01 \%- \\
473,7 \%\end{array}$ & 101 & $87,66 \%$ & 73 & $94,23 \%$ & 65 \\
\hline & $\mathbf{1 0 2}$ & & $\mathbf{8 2}$ & & $\mathbf{6 8}$ \\
\hline
\end{tabular}

Berdasarkan tabel di atas, dapat diketahui bahwa tidak terdapat pola hubungan yang berlawanan dari abnormal return yang diperoleh pada jangka pendek dan jangka panjang, yaitu bahwa berdasar atas saham yang dibeli pada harga penawaran perdana, abnormal return yang negatif pada bulan ke-1 diikuti pula pada bulan ke-6, begitu juga abnormal return yang positif pada bulan ke-1 diikuti pula pada bulan ke-6. Hal tersebut menunjukkan bahwa tidak terjadi market overreaction di Bursa Efek Indonesia atau menolak hipotesis ke-4.

\section{KESIMPULAN DAN SARAN}

Dari hasil analisis di atas dapat diambil kesimpulan bahwa ternyata terjadi underpricing yang signifikan di BEI pada tahun 2000 - 2007 dibuktikan dari hasil uji one sample t-test karena nil. Sign $(0,00)<$ alpha $(0,05)$.

Bahwa kinerja saham setelah IPO untuk jangka pendek akan dapat memberikan abnormal return yang tinggi atau mengalami outperformance. Hal ini menunjukkan jika investor ingin mendapatkan keuntungan yang tinggi ketika mereka membeli saham perdana (saat perusahaan melakukan IPO), maka harus segera menjualnya dalam jangka pendek.

Penurunan abnormal return dari jangka pendek ke jangka panjang, menunjukkan bahwa ada penurunan kinerja saham, jadi dapat disimpulkan bahwa kinerja saham setelah IPO dalam jangka panjang akan mengalami penurunan (long run underperformance).

Bahwa tidak terjadi market overreaction di Bursa Efek Indonesia pada tahun 2000 2007, karena tidak terdapat pola hubungan yang berlawanan dari abnormal return yang diperoleh pada jangka pendek dan jangka panjang. Hal ini berarti tidak ada kesalahan penilaian dari investor di BEI terhadap saham yang ditawarkan pada saat IPO karena tidak terdapat pembalikkan yang 
signifikan dimana saham losser tidak memberikan abnormal return positif yang signifikan dan begitu juga sebaliknya, atau dengan kata lain pasar tidak bereaksi secara berlebihan terhadap informasi baru. Hasil penelitian ini sejalan dengan penelitian yang dilakukan Warninda dan Asri (1997), Susiyanto (2002) serta Supriyono (2005) yang menyimpulkan tidak terjadi overreaction di BEJ.

Bagi para Investor yang menanamkan sahamnya pada saat IPO, hendaknya segera menjual kembali sahamnya dalam jangka pendek (satu atau dua bulan setelah IPO) karena dengan melakukan tindakan ini, investor akan memperoleh keuntungan (gain) yang tinggi serta jangan menahan sahamnya dalam waktu yang lama sebab harganya akan cenderung untuk turun.

\section{DAFTAR PUSTAKA}

Darmadji, T., dan Fakhruddin Hendy, M. (2001). Pasar Modal Di Indonesia: Pendekatan Tanya Jawab. Edisi Pertama. Jakarta: Salemba Empat.

Gumanti, Tatang, A. (2003). "Strategi Penetapan Harga Dalam Penawaran Saham Perdana". Wahana Jurnal Ekonomi, Manajemen dan Akuntansi. AA-YKPN. Vol. 6: 15-29.

Husnan, Suad (1998). Dasar-dasar Teori Portofolio dan Analisis Sekuritas. Edisi Ketiga. Yogyakarta: UPP AMP YKPN.

Jogiyanto (2003). Teori Portofolio dan Analisis Investasi. Edisi 3. Yogyakarta: BPFE.

Kasmir (2005). Bank dan Lembaga Keuangan Lainnya. Edisi Keenam. Jakarta: PT Raja Grafindo Persada.

Kuncoro, Mudrajad (2003). Metode Riset untuk Bisnis dan Ekonomi: Bagaimana meneliti dan menulis tesis?. Jakarta: Erlangga.
Kurniawati, I. (2006). Modul Pengolahan Data Elektronik Mengolah Data Statistik dengan SPSS 11.5. Yogyakarta: Universitas Ahmad Dahlan.

Manurung, Adler, H. dan Soepriyono, G. (2006). "Hubungan antara Imbal Hasil IPO dan Faktor-Faktor yang Mempengaruhi Kinerja IPO di BEJ". Manajemen Usahawan Indonesia. Fakultas Ekonomi Universitas Indonesia. Vol. 4: 14-26.

Mendenhall, W. dan Reinmuth, James, E. (1982). Statistik untuk Manajemen dan Ekonomi. Edisi Keempat, Jilid 1. Jakarta: Erlangga.

Murtini, U. (2005). "Kinerja Surat Berharga Setelah Initial Public Offering". Jurnal Riset Akuntansi dan Keuangan. Vol. 1, No. 2: 135-144.

Sugiyono (1999). Metode Penelitian Bisnis. Bandung: Alfabeta.

Suharyadi dan Purwanto (2004). Statistika untuk Ekonomi dan Keuangan Modern. Buku2. Jakarta: Salemba Empat.

Supriyono, E. (2005). "Penawaran Perdana Di Bursa Efek Jakarta: Apakah Terjadi Market Overreaction?". Utilitas Jurnal Manajemen dan Bisnis. Fakultas Ekonomi Universitas Muhammadiyah Yogyakarta. Vol. 14: 51-66.

Suroso (2005). "Perbedaan Kinerja Saham Antar Tahun Pelaksanaan IPO". Manajemen Usahawan Indonesia. Fakultas Ekonomi Universitas Indonesia. Vol. 9: 16-21.

Suroso dan Utama, S. (2005). "Hubungan Kinerja Jangka Panjang Saham Pasca IPO dengan Optimisme dan Divergensi Opini Investor serta Tindakan Oportunis Emiten". Manajemen Usahawan Indonesia. Fakultas Ekonomi Universitas Indonesia. Vol. 3: 27-39. 
Susilo, J. (2004). “Murphy's Law Dalam Anomali

Pasar: Analisis Terhadap Size Market dan Market Overreaction". Aplikasi Bisnis. Fakultas Ekonomi Universitas Islam Indonesia. Vol. 5, No. 6: 460-468.

Suyatmin dan Sujadi (2006). "Faktor-Faktor yang Mempengaruhi Underpricing pada
Penawaran Umum Perdana di Bursa Efek Jakarta". Benefit Jurnal Manajemen dan Bisnis. Fakultas Ekonomi Universitas Muhammadiyah Surakarta. Vol. 10: 1132.

Tandelilin, E. (2001). Analisis Investasi dan Manajemen Portofolio. Edisi Pertama. Yogyakarta.: BPFE. 